\title{
Social play changes reflect differences in biology and development of three felids
}

\author{
Anastasia L. Antonevich*, Galina S. Alekseeva, Nina A. Vasilieva, \\ Ekaterina V. Pavlova, Julia A. Loshchagina, Svetlana Yu. Duplyakina, \\ Sergey V. Naidenko
}

\begin{abstract}
Social play in young mammals reflects behavioral development, play can be affected by differences in development timing and species biology. We compared social play frequency changes in three felids: Eurasian lynx (Lynx lynx), Amur subspecies of leopard cat (Far-Eastern wildcat) (Prionailurus bengalensis euptilurus) and domestic cat (Felis catus). Social play is often expected to increase social tolerance and cohesion in a litter. Socially living domestic cat had contact and non-contact social play rates at the same level as solitary lynx and leopard cat. Whereas lynx differed from the other felids in lower social play rates at the age from one to one and a half month. Two types of social play were changing differently. Non-contact play rates, attributed to predatory skills development, were synchronized among species by age of kittens. Whereas contact play changes, attributed to communication development, were sensitive to the developmental stage. Contact play intensified in lynx much later than in the other felids probably due to a later onset of weaning. The period of extraordinary low contact play rates coincided with the onset of spontaneous sibling aggression, unique for lynx. After a period of spontaneous sibling aggression contact play rates in lynx increased to the level that other felids had. Observed social play changes and differences reflect development timing and species-specific features in felids.
\end{abstract}

How to cite this article: Antonevich A.L., Alekseeva G.S., Vasilieva N.A., Pavlova E.V., Loshchagina J.A., Duplyakina S.Yu., Naidenko S.V. 2019. Social play changes reflect differences in biology and development of three felids //Russian J. Theriol. Vol.18. No.2. P.80-90. doi: 10.15298/rusjtheriol.18.2.02

KEY WORDS: play, development, Eurasian lynx, domestic cat, leopard cat, aggression, sibling.

Anastasia L.Antonevich [anastasia-antonevich@yandex.ru],A.N. Severtsov Institute of Ecology and Evolution, Russian Academy of Sciences, Leninsky pr. 33, Moscow 119071, Russia; Galina S. Alekseeva [gal.ser.alekseeva@gmail.com], A.N. Severtsov Institute of Ecology and Evolution, Russian Academy of Sciences, Leninsky pr. 33, Moscow119071, Russia; Nina A. Vasilieva [ninavasilieva@gmail.com ], A.N. Severtsov Institute of Ecology and Evolution, Russian Academy of Sciences; Leninsky pr. 33, Moscow119071, Russia; Ekaterina V. Pavlova [pavlike@mail.ru], A.N. Severtsov Institute of Ecology and Evolution, Russian Academy of Sciences, Leninsky pr. 33, Moscow 119071, Russia; Julia A. Loshchagina [julia.loshchagina@gmail.com], Institute of Geography, Russian Academy of Sciences, Staromonetniy per. 29, Moscow 119017, Russia; Svetlana Yu. Duplyakina [dupliakina92@mail.ru], CNITI-Technomash, Ivana Franko str. 4., Moscow 121108, Russia; Sergey V. Naidenko [snaidenko@mail.ru], A.N. Severtsov Institute of Ecology and Evolution, Russian Academy of Sciences; Leninsky pr. 33, Moscow 119071, Russia.

\section{Социальная игра отражает различия в биологии и развитии трех видов кошачьих}

\author{
А.Л. Антоневич, Г.С. Алексеева, Н.А. Васильева, Е.В. Павлова, \\ Ю.А. Лощагина, С.Ю. Дуплякина, С.В. Найденко
}

РЕЗЮМЕ. Социальная игра у детенышей млекопитающих отражает развитие поведения, игра может различаться в зависимости стадий развития и биологии вида. Мы сравнили изменения частоты игры у трех видов кошачьих: евразийской рыси (Lynx lynx), дальневосточного лесного кота (амурского подвида бенгальской кошки Prionailurus bengalensis euptilurus) и домашней кошки (Felis catus). Социальную игру часто связывают с увеличением социальной толерантности и сплочением выводка. Частота социальной игры не различалась у домашней кошки, ведущей социальный образ жизни и одиночных видов рыси и дальневосточного кота. В то же время рысь отличалась от других кошачьих низкой частотой социальной игры в возрасте месяц-полтора месяца. Два типа социальной игры изменялись

* Corresponding authors 
по-разному. Неконтактная игра, которую связывают с развитием охотничьих навыков, менялась у рыси синхронно с другими видами. В то же время изменения в контактной игре, которую считают связанной с развитием коммуникации, зависели от стадии развития. Контактная игра интенсифицировалась у рыси значительно позже, чем у других кошачьих, возможно в связи с длительной лактацией и поздним началом перехода на мясной корм. Период необычно низкой частоты игры соответствовал началу проявления спонтанной внутривыводковой агрессии, уникального для рыси явления. После периода спонтанной внутривыводковой агрессии частота контактной игры у рыси увеличилась до уровня, который был у других кошачьих. Наблюдаемые изменения социальной игры отражают изменения и различия в периодах развития, а также видоспецифические особенности кошачьих.

КЛЮЧЕВЫЕ СЛОВА: игра, онтогенез, евразийская рысь, домашняя кошка, дальневосточный кот, агрессия, внутривыводковая.

\section{Introduction}

Young mammals usually grow up with their parents and develop appropriate species-specific behavior and key species adaptations. Cross-fostering or social isolation can change offspring behavior and cause abnormalities in behavioral development (Hager et al., 2009; Luchetti et al., 2015). What could be a key that indicates development of social behavior? Social play is one of the major types of early social behavior, it reflects energy supply and welfare of a young (Held \& Špinka, 2011). Moreover, it plays an important role in the development of other types of social behavior (Burghardt, 2005). Social play is similar among related species and differences are supposed to be caused by differences in social relations (Bekoff, 1974; Biben, 1983). However, to use social play as a key-behavior we need to understand the biological meaning of social play changes and differences.

Wild felids reproduce regularly in different zoos but their play development is poorly studied. The best studied species among felids, Felis catus Linnaeus, 1758 or domestic cat (West, 1974; Barrett \& Bateson, 1978; Caro, 1981; Martin \& Bateson, 1985; Mendoza \& Ramirez, 1987), is one of the few relatively social and also domesticated species in felids (Nowell \& Jackson, 1996). Play in domestic cat is similar to the play in other felid species (Fagen, 1981), but all species are unique and their specific traits are important for behavioral development. Comparative analysis of behavior in captivity can help to understand species-specific adaptations and traits. Unfortunately, information about kittens' play in solitary felid species is fragmentary and scarce. Wild felids even of the same size as domestic cat can vary in the speed of development and duration of its stages (Nowell \& Jackson, 1996). Moreover, unique traits can determine species-specific patterns of development. In lynx genera early sibling aggression is an important part of kittens' development (Sokolov et al., 1994; Vargas et al., 2005; Antonevich \& Naidenko, 2013). Fights occur in $50 \%$ of litters with 2-4 kittens in Eurasian lynx (Lynx lynx Linnaeus, 1758) and almost in all litters of Iberian lynx (Lynx pardinus Temminck, 1827) (Antonevich et al., 2009). Siblings fight mainly in the age of one-two months with a peak of probability at one and a half months. This aggression causes injuries and rarely death of a cub. Fights start spontaneously irrespective of feeding competition, hierarchy, weaning or litter resettlement periods (Sokolov et al., 1994; Antonevich et al., 2009; Naidenko \& Antonevich, 2009). Fight results are not seen in any interactions related to feeding (Antonevich et al., in prep.), but surprisingly they affect play behavior in the litter. The overall play rate among kittens decreases after the fight for a few days (Naidenko \& Antonevich, 2009) but fight affects individual differences in social play frequency. After the fight individual differences in social play rates increase among littermates (Antonevich \& Naidenko, 2008). Changes in social play responding to post-aggression social changes support the idea that play relates with species-specific features and is a good indicator of social relations.

Play frequency can reflect various social changes. It decreases in the periods of social tension like litter dissolution (Mendoza \& Ramirez, 1987) and increases in the periods of litter cohesion e.g. after sibling aggression period in spotted hyaena Crocuta crocuta Erxleben, 1777 (Drea et al., 1996). Therefore, social play is supposed to facilitate social cohesion and to reduce aggression (West, 1974; Drea et al., 1996; Burghardt, 2005; Palagi et al., 2016a, 2016b; Cordoni et al., 2018) but see also (Sharpe \& Cherry, 2003; Sharpe, 2005). In regard to Eurasian lynx we expected that social play would increase after a period of social tension, after sibling aggression in lynx (the 'Cohesive play' hypothesis) but not in two other species.

Play trains social skills for future life (Poirier \& Smith, 1974; Biben, 1983; Pellis \& Iwaniuk, 1999). Social species are expected to have more intense social play (Bekoff, 1972, 1974; Poirier \& Smith, 1974; Palagi $\&$ Cordoni, 2012) and to tolerate partners more (Palagi \& Cordoni, 2012). We expected that since domestic cat is adapted to live at high population density with intensive social interactions, the frequency of contact play would be much higher in this species than in solitary cats (the 'Social tolerance' hypothesis).

The aim of our study was to reveal key interspecific differences in social play level and their developmental changes in felids.

To do that we compared developmental changes in social play frequency in three species of felids. We studied play in Eurasian lynx (Lynx lynx), Amur subspecies of the leopard cat (Far-Eastern wildcat) (Prionailurus bengalensis euptilurus Elliot, 1871) (Kitchener et al., 
Table 1. Two developmental stages were selected for each species. Stage Milk/Meat: from the first attempt to eat meat while still suckling to the moment when meat become the main food; Stage Meat/Milk: from eating meat

(as the main food) with suckling to complete weaning.

\begin{tabular}{|c|c|c|c|c|}
\hline Age periods, days & $30-45$ & $46-60$ & $61-75$ & $76-90$ \\
\hline \multicolumn{5}{|c|}{ Species developmental stages, days } \\
\hline Eurasian lynx & Milk & Milk/Meat, 50-70 & Meat/Milk, 71-90 \\
\hline Leopard cat & Milk/Meat, 30-45 & \multicolumn{2}{|c|}{ Meat/Milk, 46-90 } \\
\hline Domestic cat & Milk/Meat, 30-45 & Meat/Milk, 46-60 & Meat \\
\hline
\end{tabular}

2017) and domestic cat (Felis catus). The selected species differed in species-specific development timing (Table 1).

As development rates vary among species, behavioral data need to be equated not only for age, but for development timing also (Biben, 1983). Weaning is a physiological milestone similar for all species (Donaldson et al., 2002). Play changes during weaning (Bateson \& Young, 1981; Martin \& Bateson, 1985; Bateson et al., 1990; Donaldson et al., 2002; Krachun et al., 2010). We suggested that play changes can be better understood when compared among species using also development timing.

\section{Methods}

\section{Husbandry conditions and animals}

Our study was conducted at Joint Usage Center "Live collection of wild species of mammals" of the A.N. Severtsov Institute of Ecology and Evolution (at the biological station Chernogolovka, Russia), located $50 \mathrm{~km}$ northeast of Moscow, Russia (ca. 56.00 $\mathrm{N}, 38.367^{\circ} \mathrm{E}$ ). We observed kittens born in captivity at the Center. This study is based on observations of 36 litters: 19 litters of the Eurasian lynx (two-four kittens in a litter, 50 kittens from five females), 6 litters of the leopard cat (two-three kittens in a litter, 14 in all from six females) and 11 litters of the domestic cat (two-five kittens in a litter, 37 in all from nine females). All litters with their mothers were housed outdoors, separately from other conspecifics. The animals were under natural temperature fluctuations and photoperiod during the investigation in 2003-2013. Every litter with a female was kept in a wire-meshed outside enclosure with partly natural environment and a wooden box as a shelter. The size of enclosure differed between species: $82 \mathrm{~m}^{2}$ for lynx, $16 \mathrm{~m}^{2}$ for leopard cat, and $2-6 \mathrm{~m}^{2}$ for domestic cat. Leopard cat and domestic cat used their enclosures in three dimensions so the roof at two $m$ height was added. Various constructions of logs and stumps were installed in each enclosure to enrich the kittens' play interactions. The litters were fed six times a week with whole chickens or their parts $(0.5-2 \mathrm{~kg}$ per every litter depending on the species) (Naidenko, 2005). The animals had water access ad libitum.

\section{Behavioral observations}

All the three felid species gave birth in spring (in May). We observed the animals in summer from June to August during a period of the most intensive play. Observations were performed for three-six h from 5:00 p.m. to 1:00 a.m., during the main peak of animal activity (Naidenko, 1997). We observed focal litters from the $30^{\text {th }}$ day of kittens' life (when lynx kittens start to go out of the den regularly) to the $90^{\text {th }}$ day (when the weaning is over in all species). For individual recognition, the kittens were marked by cutting or staining small areas of their fur (Nyanzol D fur dye). In total, we have used the data of $2715 \mathrm{~h}$ of observations in this study (1654 h for lynx, $582 \mathrm{~h}$ for leopard cat and $479 \mathrm{~h}$ for domestic cat).

The data were recorded in special protocols (20032007 for lynx and 2010-2013 for leopard cat) or in the EthoLog 2.2.5 program (Ottoni, 2000) (2009-2012, lynx and domestic cat). We used a method of continuous data recording (Martin \& Bateson, 1993). We registered play acts for all kittens in a litter during observations (each play element directed from one kitten to another, in each moment). Every play element was attributed to the initiator (agent of an action). When kittens acted equally actively and the initiator was indistinguishable we considered both contacting individuals as initiators. Most of the elements of behavior that we observed lasted no more than 10-20 seconds. However, if a play element (wrestling) lasted more than 30 seconds we considered its continuation to be a new act. We calculated for each kitten the frequency of initiation of play contacts (per one $\mathrm{h}$ of activity, excluding sleeping time). We used an ethogram developed in the previous studies of lynx behavior (Alekseeva et al., 2014). We grouped all elements of play into two general categories: contact and non-contact play (Table 2). Contact play included elements that required physical contact and close distance between pair mates (e.g. wrestling, grappling, paws play), whereas all the play that occurred without close physical contact (e.g. stalking, chasing) was categorized as non-contact. In order to analyze the developmental changes of social play frequency in kittens we used two types of periodization: age periods and developmental stages related to stages of weaning (Table 1). We averaged play frequencies obtained from each observation for every kitten over 
Table 2. Different elements of play behavior included in contact and non-contact play (* only in leopard cat and domestic cat behavior; $* *$ only in domestic cat behavior)

\begin{tabular}{|l|l|}
\hline \multicolumn{2}{|l|}{ Contact play } \\
\hline invitation & $\begin{array}{l}\text { An attempt to attract the partner's attention (focal animal touches the partner with a paw, approaches and } \\
\text { runs away turning back, etc.); play element from which the play event usually starts, often preceded by } \\
\text { affiliative vocalization. }\end{array}$ \\
\hline wrestle & $\begin{array}{l}\text { Play interaction resembling fight; one cub lies on its back and defends itself, whereas the other attacks; } \\
\text { cubs often change their roles, wrestling is never accompanied by aggressive vocalizations. }\end{array}$ \\
\hline grapple & Gripping partner with paws from above, often accompanied by pouncing. \\
\hline pounce & Sudden and sharp jumping forward on partner. \\
\hline paw play & $\begin{array}{l}\text { One partner tries to catch the forepaw of another using its own paw, and the partner either retaliates in } \\
\text { turn, pulls its paw back or hides. }\end{array}$ \\
\hline crouch & $\begin{array}{l}\text { Stationary posture with body low and belly close to the ground (Caro, 1995), consisting in freezing in a } \\
\text { tense posture, usually followed by pouncing, chasing, or further hiding. }\end{array}$ \\
\hline stalk & Slow and cautious approach to a partner on flexed legs, with body held low(Caro, 1995) . \\
\hline chase & Running after or away from a partner. \\
\hline raid & $\begin{array}{l}\text { Attempt to attract the attention of a partner when one cub runs to another and stops abruptly; usually } \\
\text { there is no response. }\end{array}$ \\
\hline approach & Movement towards a partner in tense posture with straight legs and slightly arched back. \\
\hline arch* & Arching of back at the sight of a partner \\
\hline play defense** & Defense imitation, lying on the back \\
\hline rear up $* *$ & Stance on hind paws as a partner approach \\
\hline
\end{tabular}

age periods and developmental stages. Ethical note: all work conforms to the "Guidelines for the treatment of animals in behavioral research and teaching" (Buchanan et al., 2012) and to the laws of the Russian Federation, the country where the research was conducted.

\section{Statistical analysis}

The distributions of play frequencies were rightskewed and we log-transformed them before analysis. We performed linear mixed-effect models (LMM) to analyze the effects of age period, developmental stage and species on juvenile play level using the library lme 4 in R package (Bates et al., 2015). Since developmental stages were not consistent with age periods in different species, the full model with both developmental and age factors was incomplete and contained missed cells. Thus, we performed separate analyses for age periods and developmental stages. To access the effect of age periods we constructed two sets of models (for contact play and non-contact play as dependent variables) with age period, species, age $\times$ species interaction, litter size and kitten sex as predictors. The litter size and kitten sex were included in the models as possible confounding factors. Since developmental stages were different for the three species (Table 1), we performed separated analysis of developmental stage effect for every species with stage, litter size and kitten sex as predictors in LMM. The between-species differences were estimated for Milk/Meat and Meat/Milk only.

We evaluated sets of candidate models with all combinations of predictors using model selection based on Akaike's information criterion (AICc) in the library MuMIn (Burnham \& Anderson, 2002; Bartoń, 2018). We calculated model-averaged estimates and their errors for all predictors for models with $\triangle \mathrm{AICc}<7$ (Burnham et al., 2011) since the set of models with $\triangle \mathrm{AICc}<2 \mathrm{did}$ not include all fixed effects. The kitten identity and litter identity were fitted in all models as random factors; the repeated measure design could not be used because the datasets contained missed cells. Post-hoc comparisons were performed with Tukey HSD test using emmeans package in R (Lenth, 2016). Statistical analyses were performed with software packages R 3.5.2 (R Development Core Team 2018).

\section{Results}

Total frequency of social play initiation was high in all studied species during all four age periods: the frequency averaged among all observations was $23.3 \pm 14$ initiated contacts per hour for lynx, $28.9 \pm 8.8$ for leopard 
Table 3. Effects of age period and developmental stage on kitten contact and non-contact play frequencies (log-transformed) in three felid species: Eurasian lynx (Lynx lynx, $n=50)$, leopard cat (Prionailurus bengalensis euptilura, $n=14$ ) and domestic cat (Felis catus, $n=37$ ). The explanatory variables included litter size and kitten sex; litter ID and kitten ID were fitted as random terms in LMM. Estimates $(B)$ with their standard errors and significance $(p)$ are based on the model average from models with $\triangle \mathrm{AIC}<7$. Significant effects $(p<0.05)$ are marked with bold

\begin{tabular}{|c|c|c|}
\hline \multirow{2}{*}{ Model } & \multicolumn{2}{|c|}{ Response variable } \\
\hline & Contact play & Noncontact play \\
\hline \multicolumn{3}{|c|}{ (1) Kitten age in three species } \\
\hline Intercept & $B=4.60 \pm 0.66, p<0.0001$ & $B=2.60 \pm 0.44, p<0.0001$ \\
\hline Period 2 & $B=0.53 \pm 0.17, p=0.003$ & $B=1.01 \pm 0.10, p<0.0001$ \\
\hline Period 3 & $B=0.06 \pm 0.24, p=0.8$ & $B=1.47 \pm 0.14, p<0.0001$ \\
\hline Period 4 & $B=-0.63 \pm 0.24, p=0.008$ & $B=1.27 \pm 0.14, p<0.0001$ \\
\hline $\operatorname{Lynx}(L)$ & $B=-1.06 \pm 0.34, p=0.002$ & $B=-0.75 \pm 0.24, p=0.002$ \\
\hline Leopard cat $(L c)$ & $B=0.23 \pm 0.48, p=0.6$ & $B=0.36 \pm 0.31, p=0.3$ \\
\hline Litter size & $B=-0.15 \pm 0.18, p=0.4$ & $B=-0.09 \pm 0.12, p=0.5$ \\
\hline Kitten sex (Male) & $B=0.12 \pm 0.15, p=0.4$ & $B=0.11 \pm 0.11, p=0.3$ \\
\hline Period $2: L$ & $B=0.54 \pm 0.24, p=0.02$ & $B=0.02 \pm 0.08, p=0.8$ \\
\hline Period $3: L$ & $B=1.24 \pm 0.29, p<0.0001$ & $B=0.05 \pm 0.16, p=0.7$ \\
\hline Period 4:L & $B=1.47 \pm 0.30, p<0.0001$ & $B=0.04 \pm 0.13, p=0.8$ \\
\hline Period $2: L c$ & $B=0.11 \pm 0.36, p=0.7$ & $B=0.03 \pm 0.12, p=0.8$ \\
\hline Period $3: L c$ & $B=0.54 \pm 0.40, p=0.2$ & $B=0.05 \pm 0.18, p=0.8$ \\
\hline Period $4: L c$ & $B=0.84 \pm 0.40, p=0.03$ & $B=0.07 \pm 0.23, p=0.7$ \\
\hline \multicolumn{3}{|c|}{ (2) Developmental stages in lynx (Milk, Milk/Meat, Meat/Milk) } \\
\hline Intercept & $B=3.80 \pm 0.83, p<0.0001$ & $B=1.79 \pm 0.34, p<0.0001$ \\
\hline Milk/Meat Stage & $B=1.30 \pm 0.13, p<0.0001$ & $B=1.40 \pm 0.08, p<0.0001$ \\
\hline Meat/Milk Stage & $B=0.78 \pm 0.14, p<0.0001$ & $B=1.30 \pm 0.09, p<0.0001$ \\
\hline Litter size & $B=-0.24 \pm 0.31, p=0.4$ & $B=0.05 \pm 0.12, p=0.7$ \\
\hline Kitten sex (Male) & $B=0.14 \pm 0.16, p=0.4$ & $B=0.03 \pm 0.07, p=0.6$ \\
\hline \multicolumn{3}{|c|}{ (3) Developmental stages in domestic cat (Milk/Meat, Meat/Milk, Meat) } \\
\hline Intercept & $B=4.10 \pm 0.55, p<0.0001$ & $B=2.50 \pm 0.53, p<0.0001$ \\
\hline Meat/Milk Stage & $B=0.52 \pm 0.21, p=0.02$ & $B=0.91 \pm 0.17, p<0.0001$ \\
\hline Meat Stage & $B=-0.30 \pm 0.23, p=0.2$ & $B=1.09 \pm 0.18, p<0.0001$ \\
\hline Litter size & $B=-0.03 \pm 0.13, p=0.8$ & $B=-0.05 \pm 0.13, p=0.7$ \\
\hline Kitten sex (Male) & $B=0.15 \pm 0.27, p=0.6$ & $B=0.16 \pm 0.23, p=0.5$ \\
\hline \multicolumn{3}{|c|}{ (4) Developmental stages in Leopard cat (Milk/Meat, Meat/Milk) } \\
\hline Intercept & $B=5.73 \pm 0.80, p<0.0001$ & $B=2.14 \pm 0.51, p<0.0001$ \\
\hline Meat/Milk Stage & $B=0.33 \pm 0.27, p=0.2$ & $B=1.49 \pm 0.18, p<0.0001$ \\
\hline Litter size & $B=-0.67 \pm 0.33, p=0.04$ & $B=0.10 \pm 0.20, p=0.6$ \\
\hline Kitten sex (Male) & $B=-0.20 \pm 0.31, p=0.5$ & $B=-0.08 \pm 0.18, p=0.7$ \\
\hline
\end{tabular}

cat and $34.8 \pm 21$ for domestic cat. Generally, kittens of all studied species spent the greatest part of their activity in social play.

\section{Effect of age on the level of social play}

For both contact and non-contact play the litter size and the kitten sex effects were insignificant (Table 3 ).

The best-fitted models with the lowest $\mathrm{AICc}=5794$ and the highest AICc weight (0.32) for contact play included all predictors; among them age period, species and period $\times$ species interaction effects were strong and significant (Table 3 ). The patterns of the contact play dynamics varied strongly among the three species (it conformed to the highly significant period $\times$ species interaction; Table 3, Fig. 1A). In lynx kittens the contact play frequency was low in period 1 (30-45 days), then increased significantly to 46-60 days (to period 2 , Tukey HSD test, $\mathrm{B}=-1.1 \pm 0.2, p<0.0001)$ and remained high and stable up to 90 days (during periods 2, 34 ; Tukey HSD test, $p>0.3$ ). In domestic cat the frequency 


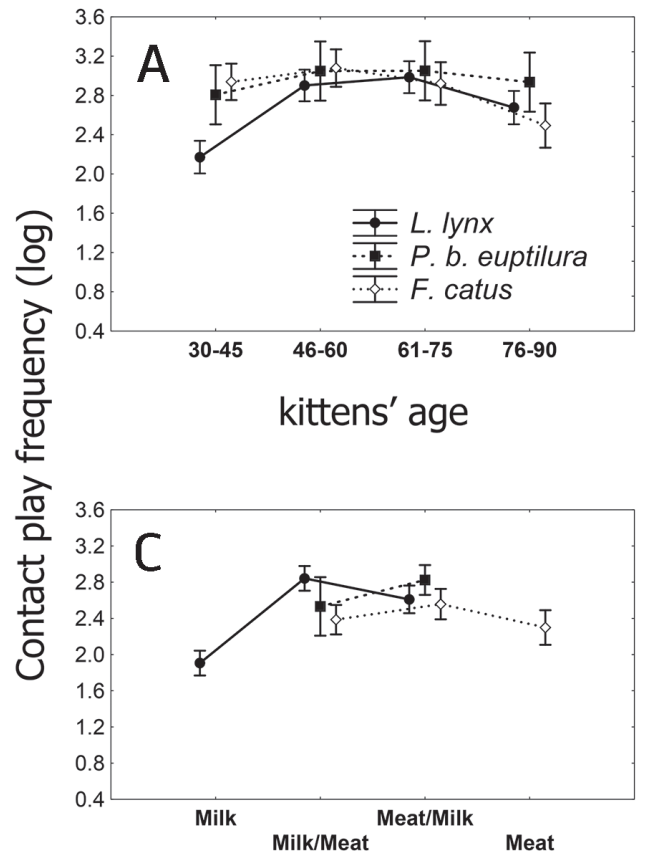

period of development

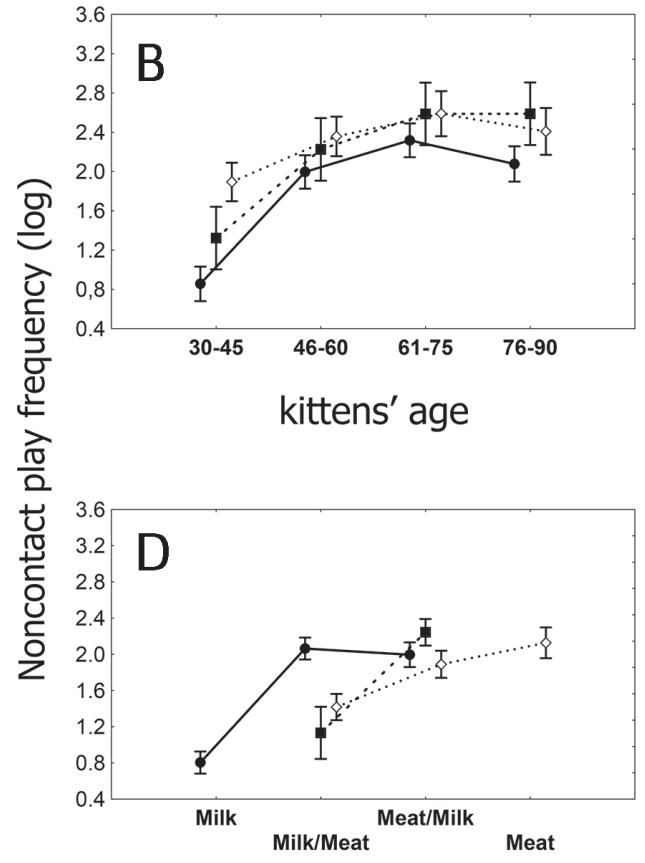

period of development

Fig. 1. Kitten social play changes in relation to 1) age and 2) development stage in three felid species: Eurasian lynx (Lynx lynx, $n=50$ ), leopard cat (Prionailurus bengalensis euptilura, $n=14$ ) and domestic cat (Felis catus, $n=37$ ). The frequencies of contact play $(\mathrm{A}, \mathrm{C})$ and non-contact play $(\mathrm{B}, \mathrm{D})$ were calculated per $1 \mathrm{~h}$ of kitten activity. All frequencies were log-transformed; see statistics in the text. Error bars represent mean $\pm 95 \%$ confidence interval.

of contact play was similar to lynx frequency (period $2-4$ for lynx; $p>0.4$ ) and did not vary significantly from 30 to 75 days (periods 1,2 and 3 , Tukey test, $p>0.9$ for all comparisons). Then it decreased slightly and during 76-90 days (period 4) the frequency was lower than in period $2(\mathrm{~B}=1.2 \pm 0.2, p=0.0001$; other differences were insignificant). In leopard cat we did not find any variation among age periods (Tukey post-hoc test, $p>0.9$ ). Any other interspecific differences were not significant (Fig. 1A).

\section{Non-contact play}

The non-contact play frequency changed synchronously in all three species (period $\times$ species interaction was insignificant; Table 3, Fig. 1B). The most parsimonious model ( $\mathrm{AICc}=4904$, AICc weight $=0.35$ ) included significant age and species effects and insignificant litter size and kitten sex effects (Table 3 ). The lowest frequency was during period 1 (30-45 days); then it increased markedly to period $2(\mathrm{~B}=-1.1 \pm 0.1, p<0.0001$ for lynx; $\mathrm{B}=-0.9 \pm 0.1, p<0.0001$ for domestic cat; $\mathrm{B}=-1.1 \pm 0.2$, $p=0.0001$ for leopard cat) and did not vary among periods 2, 3 and 4 in all species ( $p>0.1)$. The frequency of non-contact play in period 1 was lower in lynx than in domestic cat $(\mathrm{B}=1.0 \pm 0.2, p=0.01)$. Any other interspecific differences were not significant. level

Effect of development stage on the social play

Differences among the three species were not significant at both Milk/Meat and Meat/Milk stages for both types of play (LMM, $p>0.3$ ), except for the only comparison: the non-contact frequency was lower in lynx during Milk/Meat period, than in leopard cat $(\mathrm{B}=-1.2 \pm 0.3, \mathrm{p}=0.005)$.

Separate models for lynx revealed a strong stage effect for both contact and non-contact play (Table 3, Figs 1C, D). Frequencies of both types of play were low during the Milk stage as compared with Milk/ Meat $(\mathrm{B}=-1.3 \pm 0.1, p<0.0001 ; \mathrm{B}=-1.4 \pm 0.09, p<0.0001)$ and Meat/Milk $(\mathrm{B}=-0.8 \pm 0.1, p<0.0001 ; \mathrm{B}=-1.3 \pm 0.09$, $p<0.0001$ ) stages.

The level of contact play in domestic cat increased slightly but significantly from Milk/Meat to Meat/Milk stages $(\mathrm{B}=-0.5 \pm 0.2, p=0.04$; Table 3 , Fig. $1 \mathrm{C})$ and then decreased to Meat stage $(\mathrm{B}=0.8 \pm 0.2, p=0.002)$. The frequency of non-contact play (Fig. 1D) increased significantly from Milk/Meat to Meat/Milk stages $(B=0.9 \pm 0.2$, $p<0.0001)$ and was similar between the Meat/Milk and Meat stages $(\mathrm{B}=-0.2 \pm 0.2, p=0.6)$.

In leopard cat we did not find any significant variation in contact play frequency between the two ontogenetic stages, whereas the frequency of non-contact play in- 
creased strongly from Milk/Meat to Meat/Milk stage (Table 3, Figs 1C, D).

In all models we revealed a significant effect of the random term Litter ID (log-likelihood ratio test, $p<0.05$ ).

\section{Discussion}

Comparative analysis of play among studies is complicated due to variety in husbandry and in study design (Bekoff, 1974; Barrett \& Bateson, 1978; Bateson \& Young, 1981; Caro, 1981; Martin \& Bateson, 1985). Here we used the same approach for the three species and that allowed us to compare them. We expected that kittens from three different species would differ in their social play. However, the species demonstrated similarities in the average play level and in the general pattern of play frequency changes. Changes of play frequency in lynx and domestic cat conformed to the findings of other studies (West, 1974; Bateson, 2000; Alekseeva et al., 2014), the same as for cheetah Acinonyx jubatus Schreber, 1775 (Caro, 1995). The data on social play development in leopard cat presented in this study are pioneer.

Sibling play in all the three felid species did not depend on important factors known to affect play: animals' sex (Meaney et al., 1985; Mendl, 1988) and litter size (Auger \& Olesen, 2009). The absence of sexual differences in play was previously shown for domestic cat (Caro, 1981) and now we can confirm the same pattern in other felids: in lynx, with almost no sexual dimorphism, and in leopard cat, that is sexually dimorphic in adulthood but not when young (Heptner \& Sludskii, 1972; Nowell \& Jackson, 1996). Generally, sex differences are expected in the species with a high degree of sexual dimorphism (Poirier \& Smith, 1974; Llamazares-Martín et al., 2017), which young felids do not have (Nowell \& Jackson, 1996). In our study the enclosures size varied. Although it is hard to estimate possible effect of enclosure size: how much space animal needs is unclear (McPhee \& Carlstead, 2010). Smaller enclosure could cause overstimulation and increased play frequency in domestic cats, on the other hand smaller spaces are known to decrease behavioral variability in adults. Environmental complexity and possibility to exhibit natural behavior are more important that space available (Wielebnowski et al., 2002; McPhee \& Carlstead, 2010) and the most important environmental factors at the early stage of development are mother and littermates. The absence of the litter size effect contradicts the previous study on cats (Mendl, 1988), but litter size variation in our study is not so big. Moreover, play in our study was mostly dyadic and such play can be unaffected by the total group size (De Oliveira et al., 2003; Ballerini et al., 2008).

Felids are mostly solitary, but they include species with different degrees of sociality (Nowell \& Jackson, 1996), providing a good model to estimate the role of social structure. We expected that since domestic cat kittens need to prepare for future social life, they would have social play rates higher than kittens of solitary lynx and leopard cat. Our data did not support the 'Social tolerance' hypothesis: neither contact, nor non-contact social play had higher frequency in domestic cat than in other two felids, they were quite similar. It could be related to plasticity of felids social structure (Turner, 2000; Sidorovich et al., 2018). Actually relation between sociality and social play is also very contradictory or absent in many species (canids: Biben, 1983; muroid rodents: Pellis \& Iwaniuk, 1999; primates: Poirier \& Smith, 1974). It does not explain the intense and complex social play in many solitary species (Fagen, 1981; Burghardt, 2005), playful like lynx (Alekseeva et al., 2014). Besides sociality, domestication promoting bodily contacts and frequent contact play, could also increase tolerance to contacts (Trut et al., 2004; Himmler et al., 2013), but that was not the case of domestic cat, possibly, because domestic cat can be considered as a not completely domesticated species (Driscoll et al., 2009).

The species that differed mostly was lynx. Both contact and non-contact play was lower in lynx than in other felids in 30-45 days, during lynx milk stage. When we compared play among species during weaning, at the same stages for all the three species, play frequencies mostly did not differ. Pre-weaning (milk) and post-weaning (meat) stages at observed felids took place at very different ages. Play during milk stage was not observed in domestic cat and leopard cat because the period of active play related to this stage was very short. Only in lynx the milk stage was long enough to analyze play. Both contact and non-contact play were lower in lynx milk stage than in other stages. Prolonged milk dependence in lynx could influence low play intensity.

Lynx initial physical development is similar to other two felids. In the three species teeth erupt at two weeks of age; eyes open at 10-14 days in lynx and leopard cat, in domestic cat kittens at 7 days of life on average (Stehlik, 1980; Bateson, 2000; Naidenko, 2005; our own observations). Although emerging from the den at 4 weeks three felid species have different movement abilities: domestic and leopard cat are able to play intensively in the next days, whereas lynx cubs move cautiously and slowly improve their playing technics. At one month of age lynx cubs are physically less developed and this is reflected in the decreased amount of play movements they make.

Duration and timing of each developmental stage varied among the studied species. Such slow development in lynx may relate to the difference in the diet of these species. Eurasian lynx predates on mainly small ungulates (Matyushkin \& Vaisfeld, 2003) and cubs need much time to grow and develop efficient hunting. Both small cats hunt predate on rodents (Turner, 2000; Yudin, 2015). Various differences in species biology could influence the species-specific timing of developmental periods and changes of play. From two-three months lynx kittens learn to kill and eat small prey (Naidenko, 2005), start to follow mother in the wild (Molinari \& Molinari-Jobin, 2001; Naidenko, 2001; Zimmermann et al., 2005; Sidorovich et al., 2018). In enclosures, lynx females increase their vocal activity in this period and it can be attributed to efforts to keep the family together in a forest (Rutovskaya \& Naidenko, 2006). As for the leopard cat, camera traps showed that in the wild kittens 
follow their mother even at the age of 5 months (our data). The weaning of domestic cat kittens is completed long before the end of comparable period, kittens can disperse earlier than in other felids (Turner, 2000) and do not need much cohesion to the age of three months.

Play categorization varies among studies, one of the main approaches is to group play according to suggested functions (hunting, mating, etc.). Although then interpretations of play function act as definition, whereas most of play elements are ambiguous (Leyhausen \& Tonkin, 1979; Caro, 1981). We selected categorization that was strictly based on physical features of play (contact and non-contact). Using them we made data comparable for different species with some variability in ethograms and categorization. These categories were also used for cheetahs (Caro, 1995). They also have a functional significance: contact play has been attributed to intraspecific communication (Palagi et al., 2016b) and non-contact play has been attributed to predatory skills development (Caro, 1981; Fagen, 1981; Caro, 1995) following motor training hypothesis (Byers \& Walker, 1995). Play is heterogeneous, controlled by and derived from different behavioral systems (Burghardt, 2005). We suppose that contact and non-contact social play can differ in their regulation and functions. Our results also support the idea that these play types may differ functionally and thus have a different pattern of developmental changes (Caro, 1981, 1995).

Since non-contact play is attributed to predatory skills development, it might be sensitive to development timing. Although being initially lower in lynx than in domestic cat, it intensified between first and second month (from 30-45 days to 46-60 days) in all the three felids, independently of developmental stage, and it did not change later.

Contact play frequency changes differed among lynx, leopard cat and domestic cat. This type of play includes interactions important for communication development (Palagi et al., 2016a). In domestic cat the contact social play decreased from the second to the third month (from 61-75 to 76-90 days old), to the meat stage, so it could be related to preparation for disperse. Such changes confirm previous findings on the cohesive role of social play in cats (Mendoza \& Ramirez, 1987) and clarify that contact type of social play is mostly related to such developmental changes.

The increase in contact play frequency between the first and second month of kittens life was found only in lynx. Contact play frequency in lynx was very low and then rose to the same rates as in other felids. Analyzing social play by developmental periods we confirmed that play in lynx was low exactly during milk period and increased in the first weaning period. So, long-term low rates of contact play could be caused by long milk dependence.

There is a specific event in lynx litters development that occurs in this period. Spontaneous sibling aggression in lynx litters occurs mostly between first and second month (Antonevich \& Naidenko, 2007). The peak of sibling aggression probability is around the age of 45 days. The second age period (45-60 days old) or Milk/ Meat stage (50-70 days) is a post-aggression time of lynx kittens life (Antonevich \& Naidenko, 2007). It appears that contact play was low before and at the beginning of sibling aggression period and increased afterwards, confirming 'Cohesive play' hypothesis. Our expectations that play frequency would increase after the period of social tension were confirmed. An increase in play occurrence after the peak of aggression is known in other species, e.g. spotted hyena cubs (Drea et al., 1996). In domestic cat, a peak of social play frequency coincides with cohesive behavior (Mendoza \& Ramirez, 1987; this study). In canids, play intensifies before the decrease in aggression and facilitates hierarchy formation and the subsequent group action (Bekoff, 1972). Nevertheless, the real difference among lynx and other felids was not in that increase but in the very low play rate before and at the start of the fighting period. After contact play frequency increased, it became similar to frequency in other species. So, it is more likely that instead of an appeasing role of social play after the fight we should discuss a lack of play appeasing role before the fight (or immediate effect of fights on play behavior of lynx kittens) (Antonevich \& Naidenko, 2008; Naidenko \& Antonevich, 2009). Both types of play were low in lynx compared to other felids, but especially contact play, the one related to communication development (Palagi et al., 2016a).

Play can facilitate social relations (Palagi et al., 2016b). There is evidence that certain experiences in critical periods of development become essential for later behavioral expression. The period of intensive play temporally coincides with intensive synapses development in domestic cat (Byers \& Walker, 1995). Play can enforce tissues development (Brownlee, 1954) and stimulate neurogenesis (Byers \& Walker, 1995) in an appropriate period. Similar effect on neurogenesis during sensitive period can explain how social play affects communication development and how it gets a cohesive role.

Another important function of play is to reduce stress (Fagen \& Fagen, 2004; Norscia \& Palagi, 2011), it is relaxing (Fagen, 1981) and pleasurable in itself(Bekoff, 1974). Lack of play could contribute to intra litter tension. Aggression and play are not only driven by opposite motivations (Cordoni, 2009). They are competing energetically. Both behaviors are costly, they can oppose each other because of the risks that they both impose on the animal, e.g. injuries, infection or predation (Natoli et al., 2005; Vargas et al., 2005; Antonevich \& Naidenko, 2007; Kuehl et al., 2008; Antonevich et al., 2009; Naidenko \& Antonevich, 2009; Lee \& Moss, 2014).

Interaction between play and aggression develops easily in many species (Bekoff, 1974; Mendoza \& Ramirez, 1987; Paquette, 1994; Drea et al., 1996). Both types of social contacts are important in social relations and they exist in the same continuum. Social play can help to establish hierarchy (Blumstein et al., 2013) and sibling aggression is supposed to evolve when competition is high and hierarchy is not established (Drummond, 2006). Play and aggression can act together 
in maintaining hierarchical relations (Paquette, 1994; Antonevich \& Naidenko, 2008; Cordoni et al., 2018). One of the possible mechanisms is that low basic levels of play during a sensitive period could lead to difficulties in hierarchy establishment for lynx and thus favor the appearance of overt aggression.

\section{Conclusions}

Social play in felids reflects differences in species biology and responds to changes in development. Our study supports the idea that social play, in particular contact social play, may have cohesive functions. Whereas non-contact play was strongly synchronized among species by age of kittens, contact play rates were sensitive to the developmental stage. Longer milk stage in lynx coincided with low frequency of contact play comparing to other species. At two months, at the start of weaning, contact play frequency increased to the level that other felids had. We suggest that such unusually low rates of contact play could have impact on sibling aggression development in Eurasian lynx.

ACKNOWLEDGMENTS. We thank Mariya Erofeeva and Evgeny Ivanov for help, Alexander Krylovich for animal care and Ilya Timerin for veterinary help. Special thanks to Irene Sandler, English text editor. We are grateful to Dr. Kruchenkova for her valuable comments and questions that helped us to improve our manuscript. The study was supported by grants RSF 14 18-00200 (data analysis and preparing of publication), RFBR 16-34-00844-mol_a and 15-04-08529-a.

\section{References}

Alekseeva G.S., Antonevich A.L., Erofeeva M.N. \& Naidenko S.V. 2014. Social play in the development of sibling relations in Eurasian lynx (Lynx lynx) // Biology Bulletin. Vol.41. No.4. P.364-371.

Antonevich A.L. \& Naidenko S.V. 2007. [Early sibling aggression in mammals and its hormonal correlates] // Zhurnal Obshchei Biologii. Vol.68. No.4. P.307-317 [in Russian, with English summary].

Antonevich A.L. \& Naidenko S.V. 2008. Effect of sibling aggression on kittens' behavior in Eurasian lynx Lynx lynx // Acta Zoologica Sinica. Vol.54. No.11. P.12-19.

Antonevich A.L. \& Naidenko S.V. 2013. A third species of lynx, the bobcat, was found to experience early sibling aggression // CAT News. Vol.59. P.31-32.

Antonevich A.L., Naidenko S.V., Bergara J., Vasques E., Vasques A., Lopez J., Pardo A., Rivas A., Chaparro J.M., Martinez F. \& Vargas A. 2009. A comparative note on early sibling aggression in two related species: the Iberian and the Eurasian Lynx // Vargas A. (ed.) Iberian lynx ex-situ conservation: An Interdisciplinary approach. Madrid: Fundación Biodiversidad. P.156-163.

Auger A.P. \& Olesen K.M. 2009. Brain sex differences and the organisation of juvenile social play behaviour// Journal of Neuroendocrinology. Vol.21. No.6. P.519-525.
Ballerini M., Cabibbo N., Candelier R., Cavagna A., Cisbani E., Giardina I., Lecomte V., Orlandi A., Parisi G., Procaccini A., Viale M. \& Zdravkovic V. 2008. Interaction ruling animal collective behavior depends on topological rather than metric distance: Evidence from a field study // Proceedings of the National Academy of Sciences of the USA. Vol.105. No.4. P.1232-1237.

Barrett P. \& Bateson P. 1978. The development of play in cats // Behaviour. Vol.66. No.1. P.106-120.

Bartoń K. 2018. MuMIn: Multi-model inference (Version 1.42. 1).

Bates D., Mächler M., Bolker B. \& Walker S. 2015. Fitting linear mixed-effects models using lme4 // Journal of Statistical Software. Vol.67. No.1. P.1-48.

Bateson P. 2000. Behavioural development in the cat // Turner D.C., Bateson P. (eds.) The domestic cat: the biology of its behaviour. Cambridge: Cambridge University Press. P.9-23.

Bateson P., Mendl M. \& Feaver J. 1990. Play in the domestic cat is enhanced by rationing of the mother during lactation // Animal Behaviour. Vol.40. No.3. P.514-525.

Bateson P. \& Young M. 1981. Separation from the mother and the development of play in cats // Animal Behaviour. Vol.29. No.1. P.173-180

Bekoff M. 1972. The development of social interaction, play, and metacommunication in ammals: An ethological perspective // Quarterly Review of Biology. Vol.47. No.4. P.412-434.

Bekoff M. 1974. Social play and play-soliciting by infant canids // American Zoologist. Vol.14. No.1. P.323-340.

Biben M. 1983. Comparative ontogeny of social behaviour in three South American canids, the maned wolf, crab-eating fox and bush dog: Implications for sociality // Animal Behaviour. Vol.31. No.3. P.814-826.

Blumstein D.T., Chung L.K. \& Smith J.E. 2013. Early play may predict later dominance relationships in yellow-bellied marmots (Marmota flaviventris) // Proceedings of the Royal Society of London, B: Biological Sciences. Vol.280. No.1759. 20130485.

Brownlee A. 1954. Play in domestic cattle in Britain: an analysis of its nature // British Veterinary Journal. Vol.110. No.2. P.48-69.

Burghardt G.M. 2005. The genesis of animal play. Testing the limits. Cambridge: The MIT Press. 520 p.

Burnham K.P. \& Anderson D.R. 2002. Model selection and multimodel inference: a practical information-theoretic approach. New York: Springer Science \& Business Media. $488 \mathrm{p}$.

Burnham K.P., Anderson D.R. \& Huyvaert K.P. 2011. AIC model selection and multimodel inference in behavioral ecology: some background, observations, and comparisons // Behavioral Ecology and Sociobiology. Vol.65. No.1. P.23-35.

Byers J.A. \& Walker C. 1995. Refining the motor training hypothesis for the evolution of play // American Naturalist. Vol.146. No.1. P.25-40.

Caro T.M. 1981. Predatory behaviour and social play in kittens // Behaviour. Vol.76. No.1. P.1-24.

Caro T.M. 1995. Short-term costs and correlates of play in cheetahs // Animal Behaviour. Vol.49. No.2. P.333-345. 
Cordoni G. 2009. Social play in captive wolves (Canis lupus): not only an immature affair // Behaviour. Vol.146. No.10. P.1363-1385.

Cordoni G., Norscia I., Bobbio M. \& Palagi E. 2018. Differences in play can illuminate differences in affiliation: A comparative study on chimpanzees and gorillas // PLoS ONE. Vol.13. No.3. e0193096.

De Oliveira C.R., Ruiz-Miranda C.R., Kleiman D.G. \& Beck B.B. 2003. Play behavior in juvenile golden lion tamarins (Callitrichidae: Primates): organization in relation to costs // Ethology. Vol.109. No.7. P.593-612.

Donaldson T.M., Newberry R.C., Špinka M. \& Cloutier S. 2002. Effects of early play experience on play behaviour of piglets after weaning // Applied Animal Behaviour Science. Vol.79. No.3. P.221-231.

Drea C.M., Hawk J.E. \& Glickman S.E. 1996. Aggression decreases as play emerges in infant spotted hyaenas: preparation for joining the clan // Animal Behaviour. Vol.51. No.6. P.1323-1336.

Driscoll C.A., Macdonald D.W. \& O’Brien S.J. 2009. From wild animals to domestic pets, an evolutionary view of domestication // Proceedings of the National Academy of Sciences of the USA. Vol.106. Suppl.1. P.9971-9978.

Drummond H. 2006. Dominance in vertebrate broods and litters // Quarterly Review of Biology. Vol.81. No.1. P.3-32.

Fagen R. 1981. Animal play behavior New York: Oxford University Press. 684 p.

Fagen R. \& Fagen J. 2004. Juvenile survival and benefits of play behaviour in brown bears, Ursus arctos // Evolutionary Ecology Research. Vol.6. P.89-102.

Hager R., Cheverud J.M. \& Wolf J.B. 2009. Change in maternal environment induced by cross-fostering alters genetic and epigenetic effects on complex traits in mice // Proceedings of the Royal Society, B: Biological Sciences. Vol.276. No.1669. P.2949-2954.

Held S.D.E. \& Špinka M. 2011. Animal play and animal welfare // Animal Behaviour. Vol.81. No.5. P.891-899.

Heptner V.H. \& Sludskii A.A. 1972. [Carnivores (Feloidea)]. Moscow: Vysshaya Shkola. 550 p. [In Russian].

Himmler B.T., Stryjek R., Modlinska K., Derksen S.M., Pisula W. \& Pellis S.M. 2013. How domestication modulates play behavior: a comparative analysis between wild rats and a laboratory strain of Rattus norvegicus // Journal of Comparative Psychology. Vol.127. No.4. P.453-464.

Kitchener A.C., Breitenmoser-Würsten C., Eizirik E., Gentry A., Werdelin L., Wilting A., Yamaguchi N., Abramov A.V., Christiansen P., Driscoll C.A., Duckworth J.W., Johnson W.E., Luo S.J., Meijaard E., O'Donoghue P., Sanderson J., Seymour K., Bruford M.W., Groves C., Hoffmann M., Nowell K., Timmons Z. \& Tobe S.S. 2017. A revised taxonomy of the Felidae. The final report of the Cat Classification Task Force of the IUCN/SSC Cat Specialist Group // CAT News. No.11. P.1-80.

Krachun C., Rushen J. \& de Passillé A.M. 2010. Play behaviour in dairy calves is reduced by weaning and by a low energy intake // Applied Animal Behaviour Science. Vol.122. No.2-4. P.71-76.

Kuehl H.S., Elzner C., Moebius Y., Boesch C. \& Walsh P.D. 2008. The price of play: self-organized infant mortality cycles in chimpanzees // PLoS ONE. Vol.3. No.6. e2440.
Lee P.C. \& Moss C.J. 2014. African elephant play, competence and social complexity // Animal Behavior and Cognition. Vol.1. No.2. P.144-156.

Lenth R. 2016. Package 'lsmeans' http://cran.cnr.berkeley.edu/ web/packages/lsmeans/lsmeans.pdf

Leyhausen P. \& Tonkin B.A. 1979. Cat behaviour. The predatory and social behaviour of domestic and wild cats. New York: Garland STPM Press. 340 p.

Llamazares-Martín C., Scopa C., Guillén-Salazar F. \& Palagi E. 2017. Strong competition does not always predict play asymmetry: the case of South American sea lions (Otaria flavescens) // Ethology. Vol.123. No.4. P.270-282.

Luchetti A., Oddi D., Lampis V., Centofante E., Felsani A., Battaglia M. \& D'Amato F.R. 2015. Early handling and repeated cross-fostering have opposite effect on mouse emotionality // Frontiers in behavioral neuroscience. Vol.9. P.93.

Martin P. \& Bateson P. 1985. The influence of experimentally manipulating a component of weaning on the development of play in domestic cats // Animal Behaviour. Vol.33. No.2. P.511-518.

Martin P. \& Bateson P. 1993. Measuring behaviour. An Introductory guide. Cambridge: Cambridge University Press. $222 \mathrm{p}$.

Matyushkin E.N. \& Vaisfeld M.A. 2003. [The lynx. Regional features of ecology, use and protection]. Moscow: Nauka. 523 p. [In Russian].

McPhee M.E. \& Carlstead K. 2010. The importance of maintaining natural behaviors in captive mammals // Kleiman D.G. et al. (eds.) Wild mammals in captivity: Principles and techniques for zoo management. Chicago: University of Chicago Press. P.303-313.

Meaney M.J., Stewart J. \& Beatty W.W. 1985. Sex differences in social play: the socialization of sex roles // Advances in the Study of Behavior. Vol.15. P.1-58.

Mendl M. 1988. The effects of litter size variation on mother-offspring relationships and behavioural and physical development in several mammalian species (principally rodents) // Journal of Zoology. Vol.215. P.15-34.

Mendoza D.L. \& Ramirez J.M. 1987. Play in kittens (Felis domesticus) and its association with cohesion and aggression // Bulletin of the Psychonomic Society. Vol.25. No.1. P.27-30.

Molinari P. \& Molinari-Jobin A. 2001. Behavioural observations of interactions in a free-ranging lynx Lynx lynx family at kills // Acta Theriologica. Vol.46. No.4. P.441-445.

Naidenko S.V. 2001. Aggression in lynx adults-cubs relations: can it be a reason of litters dissolution? // Ethology Ecology \& Evolution. Vol.13. No.3. P.283-295.

Naidenko S.V. 2005. [Features of reproduction and postnatal development of Eurasian lynx] Moscow: KMK Scientific Press. 112 p. [In Russian, with English summary].

Naidenko S.V. \& Antonevich A.L. 2009. Sibling aggression in Eurasian lynx (Lynx lynx) // Vargas A. (ed.) Iberian Lynx Ex-situ Conservation: An Interdisciplinary Approach. Madrid, Spain: Fundación Biodiversidad. P.146-155.

Natoli E., Say L., Cafazzo S., Bonanni R., Schmid M. \& Pontier D. 2005. Bold attitude makes male urban feral domestic cats more vulnerable to feline immunodeficiency virus // Neuroscience \& Biobehavioral Reviews. Vol.29. No.1. P.151-157. 
Norscia I. \& Palagi E. 2011. When play is a family business: adult play, hierarchy, and possible stress reduction in common marmosets // Primates. Vol.52. No.2. P.101-104.

Nowell K. \& Jackson P. 1996. Wild Cats. Status Survey and Conservation Action Plan. IUCN/SSC Cat Specialist Group. Gland: IUCN. 382 p.

Ottoni E.B. 2000. EthoLog 2.2: a tool for the transcription and timing of behavior observation sessions // Behavior Research Methods, Instruments \& Computers. Vol.32. No.3. P.446-449.

Palagi E., Burghardt G.M., Smuts B., Cordoni G., Dall'Olio S., Fouts H.N., Řeháková-Petrů M., Siviy S.M. \& Pellis S.M. 2016a. Rough-and-tumble play as a window on animal communication // Biological Reviews. Vol.91. No.2. P.311-327.

Palagi E. \& Cordoni G. 2012. The right time to happen: Play developmental divergence in the two Pan species // PLoS ONE. Vol.7. No.12. e52767.

Palagi E., Cordoni G., Demuru E. \& Bekoff M. 2016b. Fair play and its connection with social tolerance, reciprocity and the ethology of peace// Behaviour. Vol.153. No.9-11. P.1195-1216.

Paquette D. 1994. Fighting and playfighting in captive adolescent chimpanzees // Aggressive Behavior. Vol.20. No.1. P.49-65.

Pellis S.M. \& Iwaniuk A.N. 1999. The roles of phylogeny and sociality in the evolution of social play in muroid rodents // Animal Behaviour. Vol.58. No.2. P.361-373.

Poirier F.E. \& Smith E.O. 1974. Socializing Functions of Primate Play // American Zoologist. Vol.14. No.1. P.275-287.

Rutovskaya M.V. \& Naidenko S.V. 2006. [Acoustic communication of lynx (Lynx lynx)] // Bulletin MOIP. Vol.111. No.1. P.3-9 [in Russian, with English summary].
Sharpe L.L. 2005. Play does not enhance social cohesion in a cooperative mammal // Animal Behaviour. Vol.70. No.3. P.551-558.

Sharpe L.L. \& Cherry M.I. 2003. Social play does not reduce aggression in wild meerkats // Animal Behaviour. Vol.66. No.5. P.989-997.

Sidorovich V., Gouwy J. \& Rotenko I. 2018. Unknown Eurasian lynx Lynx lynx: new findings on the species ecology and behaviour. Minsk: Minsk Chatyry Chverci. 276 p.

Sokolov V.E., Naidenko S.V. \& Serbenyuk M.A. 1994. Specific fights of young lynxes (Felis lynx, Carnivora, Felidae) // Zoologicheskii Zhurnal. Vol.73. No.1. P.132-138 [in Russian with English summary].

Trut L.N., Plyusnina I.Z. \& Oskina I.N. 2004. An experiment on fox domestication and debatable issues of evolution of the dog // Russian Journal of Genetics. Vol.40. No.6. P.644-655.

Turner D.C. 2000. The domestic cat: The biology of its behaviour. Cambridge: Cambridge University Press. 256 p.

Vargas A., Martínez F., Bergara J., Klink L.D., Rodríguez J. \& Rodríguez D. 2005. Update on the Iberian lynx Ex-situ Conservation Program // CAT News. No.43. P.14-15.

West M. 1974. Social play in the domestic cat // American Zoologist. Vol.14. No.1. P.427-436.

Wielebnowski N.C., Fletchall N., Carlstead K., Busso J.M. \& Brown J.L. 2002. Noninvasive assessment of adrenal activity associated with husbandry and behavioral factors in the North American clouded leopard population // Zoo Biology. Vol.21. No.1. P.77-98.

Yudin V.G. 2015. [Far Eastern wildcat]. Vladivostok: Dalnauka. 442 p. [In Russian].

Zimmermann F., Breitenmoser-Würsten C. \& Breitenmoser U. 2005. Natal dispersal of Eurasian lynx (Lynx lynx) in Switzerland // Journal of Zoology. Vol.267. No.4. P.381-395. 